\title{
KEMAMPUAN PENALARAN MATEMATIS SISWA MENGGUNAKAN PENDEKATAN METAPHORICAL THINKING PADA MATERI PERBANDINGAN KELAS VIII DI SMPN 1 INDRALAYA UTARA
}

\author{
Intan Saputri ${ }^{1}$, Ely Susanti ${ }^{2}$, Nyimas Aisyah ${ }^{3}$ \\ ${ }^{1,2,3}$ Program Studi Pendidikan Matematika FKIP Universitas Sriwijaya \\ intans777@gmail.com
}

\begin{abstract}
Abstrak
Penelitian ini merupakan penelitian deskriptif yang bertujuan untuk mendeskripsikan kemampuan penalaran matematis siswa menggunakan pendekatan metaphorical thinking pada materi perbandingan kelas VIIIA SMPN 1 Indralaya Utara. Teknik pengumpulan data menggunakan metode tes dan wawancara. Instrumen tes yang digunakan adalah soal uraian yang berjumlah 3 soal kemampuan penalaran. Teknik analisis data dilakukan dengan menganalisis hasil data tes. Wawancara digunakan untuk mendukung hasil tes siswa. Hasil penelitian menunjukkan bahwa kemampuan penalaran matematis siswa kelas VIIIA di SMP negeri 1 Indralaya Utara dikategorikan cukup, dengan rincian sebagai berikut: persentase kemampuan penalaran matematis sangat baik sebesar 6,25\%, untuk kategori baik sebesar 28,12\%, untuk kategori cukup sebesar 59,38\%, untuk kategori sedang sebesar 6,25\%, dan untuk kategori kurang sebesar 0\%. Indikator kemampuan penalaran matematis dengan persentase tertinggi yaitu menyajikan pernyataan matematika secara tertulis sebesar 92,97\%, sedangkan indikator kemampuan penalaran dengan persentase terendah yaitu menemukan pola untuk membuat generalisasi yaitu sebesar $28,91 \%$.
\end{abstract}

Kata Kunci: Pembelajaran Matematika, Kemampuan Penalaran Matematis, Pendekatan Metaphorical Thinking

\begin{abstract}
This research is a descriptive research that aims to descrcibe students' mathematical reasoning ability by metaphorical thinking approach in proportion section at grade VIIIA SMPN 1 Indralaya Utara. Data collection technique uses test and interview methods. The test instrument used is included of three reasoning ability problems. Data analysis technique is done by analysing the result of test. The interview is used for supporting the result of students' test. The result of this research shows that the mathematical reasoning ability of students at grade VIIIA of SMP Negeri 1 Indralaya Utara is medium with this details: percentage of students who have mathematical reasoning ability with category excellent is $6,25 \%, 28,12 \%$ have mathematical reasoning ability with category good, $59,38 \%$ have mathematical reasoning ability with category medium, 6,25\% have mathematical reasoning ability with category bad, and $0 \%$ for mathematical reasoning ability with category very bad. Indicator of mathematical reasoning ability with the highest percentage is presenting written mathematical statement with $91,41 \%$ while indicator with the lowest percentage is finding out the pattern or character of mathematical indication for making generalization with $31,25 \%$.
\end{abstract}

Keywords: Mathematics Learning, Mathematical Reasoning Ability, Metaphorical Thinking Approach 


\section{PENDAHULUAN}

National Council of Teachers of Mathematics (NCTM) (2000) menetapkan salah satu standar proses yang harus dimiliki siswa yaitu penalaran (reasoning). Ball, Lewis \& Thamel (Widjaya, 2010) menyatakan bahwa "mathematical reasoning is the foundation for the construction of mathematical knowledge". Hal ini berarti penalaran matematika adalah fondasi untuk mendapatkan atau menkonstruk pengetahuan matematika. De Lange ( 2006) juga menyatakan bahwa salah satu kemampuan yang harus dipelajari dan dikuasai para peserta didik selama proses pembelajaran matematika di kelas yaitu kemampuan penalaran matematis. Berdasarkan pendapat-pendapat tersebut, kemampuan penalaran merupakan salah satu kemampuan yang harus dimilik siswa yang dapat dikembangkan melalui pembelajaran matematika.

Berdasarkan laporan hasil The Trends in International Mathematics and Science Study (TIMSS) tahun 2011 bahwa Indonesia berada di peringkat 41 dari 45 peserta. Setiadi, dkk. (2012) menyatakan bahwa salah satu faktor rendahnya hasil TIMSS 2011 yang dicapai oleh Indonesia dikarenakan kurang terlatihnya peserta didik dalam menyelesaikan soal-soal yang menuntut penalaran. Peserta didik Indonesia rata-rata dapat menjawab benar soal-soal pada domain kognitif penalaran hanya sebesar 17\%, yang mana domain kognitif penalaran merupakan persentase terendah dari jawaban benar peserta didik Indonesia di samping domain pengetahuan yang sebesar $31 \%$ dan domain penerapan sebesar $23 \%$.

Berdasarkan hasil wawancara peneliti dengan guru mata pelajaran matematika kelas VIII SMP Negeri 1 Indralaya Utara bahwa hasil belajar siswa masih tergolong rendah. Hal ini dapat dilihat dari hasil belajar siswa yang mencapai KKM hanya 12,5\%. Maarif dan Rahman (2014) mengemukakan bahwa kemampuan penalaran berperan penting dalam hasil belajar siswa. Hasil belajar yang tinggi menunjukkan kemampuan penalaran yang baik, sebaliknya hasil belajar yang rendah menunjukkan kemampuan penalaran yang rendah pada siswa tersebut.

Setiadi, dkk. (2012) menyatakan bahwa penalaran dapat secara langsung meningkatkan hasil belajar peserta didik, yaitu jika peserta didik diberi kesempatan untuk menggunakan keterampilan bernalarnya dalam melakukan pendugaan-pendugaan berdasarkan pengalaman sendiri, sehingga peserta didik akan lebih mudah memahami konsep. Salah satu pendekatan pembelajaran yang dapat membantu siswa mengembangkan kemampuan penalarannya yaitu pendekatan metaphorical thinking. 
Hendriana (2012) mengemukakan bahwa Metaphorical thinking merupakan jembatan antara model dan interpretasi, memberikan peluang yang besar kepada siswa untuk mengeksploitasi pengetahuannya dalam belajar matematika, dan melalui metaphorical thinking proses belajar siswa menjadi bermakna karena siswa dapat melihat hubungan antara konsep yang dipelajarinya dengan konsep yang telah dikenalnya. Dalam metaphorical thinking konsep-konsep abstrak dimetaforakan menjadi objek-objek nyata yang ada dalam kehidupan sehari-hari. Karakteristik dari pendekatan metaphorical thinking adalah menjembatani konsep-konsep yang abstrak menjadi hal yang lebih konkrit.

Penelitian mengenai pembelajaran matematika dengan pendekatan metaphorical thinking telah banyak dilakukan dengan fokus penelitian yang beragam dan menghasilkan kesimpulan yang beraneka ragam pula. Pada penelitian Afrilianto (2012), Mukhtar (2013), dan Muthmainnah (2014) menggunakan pendekatan metaphorical thinking dalam proses pembelajarannya, namun aspek yang diteliti oleh mereka tampak berbeda. Pada penelitian Afrilianto (2012) aspek yang diteliti yaitu pemahaman konsep dan kompetensi strategis matematis siswa SMP pada konten geometri materi bangun ruang sisi datar, penelitian Mukhtar (2013) yang diteliti adalah kemampuan abstraksi dan generalisasi matematis siswa SMP dengan konten bilangan pada materi barisan dan bilangan, serta penelitian Muthmainnah (2014) aspek yang diteliti yaitu kemampuan representasi matematis siswa pada konten geometri materi segitiga dan segiempat.

Namun pada penelitian ini, aspek yang akan diteliti oleh penulis dalam pembelajaran menggunakan pendekatan metaphorical thinking yaitu kemampuan penalaran matematis siswa pada materi perbandingan kelas VIII. Pada materi perbandingan kelas VIII tersebut masih banyak peserta didik yang kesulitan membedakan antara perbandingan senilai dan perbandingan berbalik nilai. (Raharjanti, Nusantara, dan Mulyati, 2016) juga menyatakan bahwa peserta didik masih belum memahami jika terdapat suatu permasalahan, apakah permasalahan tersebut merupakan perbandingan senilai atau perbandingan berbalik nilai, sehingga peserta didik juga merasa kesulitan dalam menyelesaikannya.

Berdasarkan permasalahan tersebut, peneliti ingin melakukan penelitian untuk mendeskripsikan Kemampuan Penalaran Matematis Siswa Menggunakan Pendekatan Metaphorical Thinking pada Materi Perbandingan Kelas VIII di SMPN 1 Indralaya Utara.

\section{METODE}

Penelitian ini merupakan penelitian deskriptif yang bertujuan untuk mengetahui gambaran kemampuan penalaran matematis siswa menggunakan pendekatan Metaphorical 
Thinking di SMP Negeri 1 Indralaya Utara. Kemampuan penalaran matematis siswa dalam penelitian ini adalah kemampuan siswa menyelesaikan soal-soal penalaran matematis yang diukur melalui tes tertulis setelah pembelajaran menggunakan pendekatan metaphorical thinking. Tes dinilai menggunakan indikator kemampuan penalaran matematis, yaitu : 1) Menyajikan pernyataan matematika secara tertulis, 2) Memperkirakan jawaban dengan menggunakan data yang mendukung, 3) Melakukan manipulasi matematika, 4) Memberikan alasan dengan menggunakan model, fakta, sifat-sifat, dan hubungan, 5) Menarik kesimpulan dari pernyataan, 6) Memeriksa perkiraan jawaban yang telah ditentukan, 7) Menemukan pola atau sifat dari gejala matematis untuk membuat generalisasi. Subjek dalam penelitian ini adalah siswa kelas VIIIA SMP Negeri 1 Indralaya Utara pada semester genap tahun ajaran 2015/2016. Pengambilan subjek dilakukan secara purposif (bertujuan).

Adapun prosedur penelitian yang dilaksanakan, yaitu: pada tahap persiapan, menyiapkan instrumen yang akan digunakan dalam penelitian dan melakukan validasi instrumen. Tahap pelaksanaan, pembelajaran yang berdasarkan Rencana Pelaksanaan Pembelajaran (RPP) pendekatan Metaphorical Thinking dan pelaksanaan tes kemampuan penalaran matematis. Tahap analisis data yang dilakukan setelah semua proses kegiatan belajar dalam kelas berakhir, maka data yang didapat kemudian dianalisis sesuai dengan prosedur yang telah ditetapkan.

Dalam penelitian ini data dikumpulkan melalui tes tertulis yang bertujuan untuk mengetahui kemampuan penalaran matematis siswa. Tes berbentuk uraian atau essay yang dilaksanakan di akhir penelitian. Soal disesuaikan dengan indikator-indikator kemampuan penalaran matematis. Sebelum digunakan, soal-soal tes divalidasi oleh pakar.

Wawancara dalam penelitian ini digunakan untuk mengetahui gambaran kemampuan penalaran matematis siswa dan sebagai data pendukung hasil tes siswa. Wawancara dilakukan setelah tes diberikan. Jenis wawancara yang digunakan adalah wawancara tidak terstruktur, yang mana peneliti tidak menggunakan pedoman wawancara yang telah tersusun secara sistematis dan lengkap untuk pengumpulan datanya.

Pada analisis data tes, adapun pedoman penskoran yang digunakan adalah sebagai berikut :

Tabel 1. Rubrik Penskoran Soal Penalaran

\begin{tabular}{cl}
\hline Skor & \multicolumn{1}{c}{ Indikator Penskoran } \\
\hline 4 & Jawaban sempurna, respon (penyelesaian) diberikan secara lengkap dan benar \\
\hline 3 & $\begin{array}{l}\text { Jawaban benar, tapi respon (penyelesaian) diberikan memiliki satu kesalahan } \\
\text { yang signifikan }\end{array}$ \\
\hline 2 & Jawaban benar secara parsial, namun respon (penyelesaian) yang diberikan \\
\hline
\end{tabular}




\begin{tabular}{ll}
\hline & mengandung lebih dari satu kesalahan/kekurangan yang signifikan \\
\hline 1 & $\begin{array}{l}\text { Jawaban salah, respon (penyelesaian) tidak terselesaikan secara keseluruhan } \\
\text { namun mengandung sekurang-kurangnya satu argumen yang benar }\end{array}$ \\
\hline 0 & $\begin{array}{l}\text { Jawaban salah, respon (penyelesaian) didasarkan pada proses atau argumen yang } \\
\text { salah atau tidak mengandung respon sama sekali }\end{array}$ \\
\hline
\end{tabular}

(modifikasi Thomson, 2006)

Dalam menentukan kategori tingkat kemampuan penalaran siswa dalam menyelesaikan soal-soal. Nilai kemampuan penalaran matematis siswa dikonversikan dalam bentuk kualitatif dengan memperhatikan pedoman penilaian seperti ditunjukkan tabel berikut:

Tabel 2. Nilai Kualitatif Kemampuan Penalaran Siswa

\begin{tabular}{|c|c|}
\hline Nilai & Kategori \\
\hline $81-100$ & Sangat Baik \\
$61-80$ & Baik \\
$41-60$ & Cukup \\
$21-40$ & Kurang \\
$0-20$ & Sangat Kurang \\
\hline
\end{tabular}

(Modifikasi Arikunto, 2011)

Adapun tahap awal dalam analisis data wawancara yaitu proses pemilihan, pemusatan perhatian data kasar yang muncul dari catatan lapangan (reduksi data). Dalam penelitian kualitatif, data masih berupa data mentah yang jumlahnya sangat banyak yang bersifat sangat deskriptif sehingga tidak dapat langsung dianalisis. Data wawancara dikonversikan dalam bentuk tulisan atau transkip percakapan. Kemudian peneliti memilih beberapa bagian percakapan yang dapat diproses pada langkah selanjutnya.

Selanjutnya, untuk mengurangi kesalahan penulisan pada transkip hasil wawancara, maka akan digunakan kode dalam penulisannya, misal nya $\mathrm{P}$ dan $\mathrm{S}$. P sebagai peneliti dan $\mathrm{S}$ sebagai siswa. Setelah data direduksi, langkah selanjutnya adalah penyajian data. Data disajikan dalam bentuk transkip percakapan antara peneliti dan siswa yang dimasukkan pada sebuah kolom. Langkah terakhir adalah penarikan kesimpulan, merupakan proses perumusan makna dari hasil wawancara yang diungkapkan dengan kalimat yang singkat-padat dan mudah dipahami.

\section{HASIL DAN PEMBAHASAN}

Penelitian dilakukan dengan pembelajaran menggunakan pendekatan Metaphorical Thinking untuk mendeskripsikan kemampuan penalaran matematis pada materi Perbandingan 
kelas VIII di SMP Negeri 1 Indralaya Utara yang dilaksanakan pada 17-24 Mei 2016. Penelitian dilaksanakan selama 3 pertemuan (7 jam pelajaran).

Pelaksanaan pembelajaran dengan menggunakan pendekatan Metaphorical Thinking yaitu siswa dihadapkan pada masalah kontekstual mengenai materi perbandingan senilai dan berbalik nilai. Selanjutnya, siswa mengidentifikasi konsep-konsep utama. Dalam mengidentifikasi konsep-konsep utama, siswa mengumpulkan data dan informasi dari permasalahan tersebut, serta mulai menjawab pertanyaan-pertanyaan yang tertera di Lembar Kerja Peserta Didik (LKPD). Dalam mengumpulkan data dan informasi dari suatu permasalahan, siswa menyebutkan apa yang diketahui dan ditanya dari permasalahan tersebut.

Kemudian guru memberikan contoh metafora dari suatu permasalahan perbandingan yang berbeda dari LKPD. Misalnya, pada materi perbandingan senilai guru memberikan metafora mengenai banyaknya kata yang diketik per menit dan besarnya biaya penginapan jika menginap lebih lama. Kemudian siswa membuat hubungan ide ataupun model matematika dengan fenomena dari permasalahan permasalahan yang mereka kerjakan di LKPD. langkah terakhir yaitu siswa bertukar metafora dengan teman yang lain, berdiskusi mengenai alasan pemilhan metafora yang mereka buat, dan diakhiri dengan membuat kesimpulan.

Data tes diperoleh dari analisis jawaban siswa berdasarkan acuan pedoman penskoran kemampuan penalaran matematis. Adapun skor kemampuan penalaran matematis siswa setelah diterapkan pendekatan Metaphorical Thinking dapat dilihat pada Tabel 3 berikut.

Tabel 3. Kategori Kemampuan Penalaran Matematis Siswa

\begin{tabular}{cccc}
\hline Nilai & Kategori & Frekuensi & Persentase \\
\hline $\mathbf{8 1 - 1 0 0}$ & Sangat Baik & 2 & $6,25 \%$ \\
$\mathbf{6 1 - 8 0}$ & Baik & 9 & $28,12 \%$ \\
$\mathbf{4 1 - 6 0}$ & Cukup & 19 & $59,38 \%$ \\
$\mathbf{2 1 - 4 0}$ & Kurang & 2 & $6,25 \%$ \\
$\mathbf{0 - 2 0}$ & Sangat Kurang & 0 & $0 \%$ \\
& Jumlah & $\mathbf{3 2}$ & $\mathbf{1 0 0} \%$ \\
\hline
\end{tabular}

Tabel 3 merupakan hasil penilaian tes kemampuan penalaran matematis siswa dengan jumlah rentang penilaian $0-100$ yang disajikan dalam bentuk distribusi frekuensi untuk memudahkan membaca data dan disertai dengan kategori penilaian yaitu sangat baik, baik, cukup, kurang, dan sangat kurang. 6,25\% siswa termasuk kategori sangat baik, 28,12 \% siswa termasuk kategori baik, 59,38 \% siswa termasuk kategori cukup, 6,25\% siswa 
termasuk kategori kurang, dan $0 \%$ siswa termasuk kategori sangat kurang. Rata-rata skor akhir keseluruhan siswa yaitu 58,54.

Berikut adalah persentase ketercapaian tiap-tiap indikator kemampuan penalaran matematis terlihat pada Tabel 4.

Tabel 4. Persentase Ketercapaian Indikator Kemampuan Penalaran Matematis Siswa pada Soal Tes

\begin{tabular}{clc}
\hline No & \multicolumn{1}{c}{ Indikator } & Persentase \\
\hline 1 & Menyajikan pernyataan matematika secara tertulis & $92,97 \%$ \\
\hline 2 & Memperkirakan jawaban dengan menggunakan data yang mendukung & $70,31 \%$ \\
\hline 3 & Melakukan manipulasi matematika & $78,13 \%$ \\
\hline \multirow{2}{*}{4} & $\begin{array}{l}\text { Memberikan alasan dengan menggunakan model, fakta, sifat-sifat, dan } \\
\text { hubungan }\end{array}$ & $64,84 \%$ \\
\hline 5 & Menarik kesimpulan dari pernyataan & $38,02 \%$ \\
\hline 6 & Memeriksa perkiraan jawaban yang telah ditentukan & $46,88 \%$ \\
\hline 7 & Menemukan pola untuk membuat generalisasi & $28,91 \%$ \\
\hline
\end{tabular}

Berdasarkan Tabel 4 terlihat bahwa persentase kemunculan indikator kemampuan penalaran matematis paling tinggi yaitu menyajikan pernyataan matematika secara tertulis sebesar 92,97 \%. Sementara persentase kemunculan indikator kemampuan penalaran yang paling rendah yaitu indikator menemukan pola untuk membuat generalisasi yaitu sebesar $28,91 \%$.

Berdasarkan hasil tes kemampuan penalaran, terdapat sekitar 9 siswa atau 28,12\% siswa yang nilainya merupakan kategori baik. Peneliti melakukan analisis data siswa yang dikategorikan baik. Siswa dengan kemampuan penalaran baik telah memenuhi enam indikator kemampuan penalaran dari tujuh indikator kemampuan penalaran yang ada. Adapun keenam indikator yang terpenuhi yaitu menyajikan pernyataan matematika secara tertulis, memperkirakan jawaban dengan menggunakan data yang mendukung, menarik kesimpulan dari pernyataan, melakukan manipulasi matematika, memberikan alasan dengan menggunakan model, fakta, sifat-sifat, dan hubungan, dan memeriksa perkiraan jawaban yang telah ditentukan.

Sedangkan indikator kemampuan penalaran yang tidak terpenuhi oleh siswa tersebut yaitu, menemukan pola untuk membuat generalisasi. Siswa dengan kemampuan penalaran baik tidak dapat menemukan pola untuk membuat generalisasi dikarenakan siswa masih belum memahami maksud dari variabel $n$ sehingga tidak menyelesaikan soal tersebut. Berikut jawaban dan cuplikan wawancara peneliti ke siswa tersebut. 


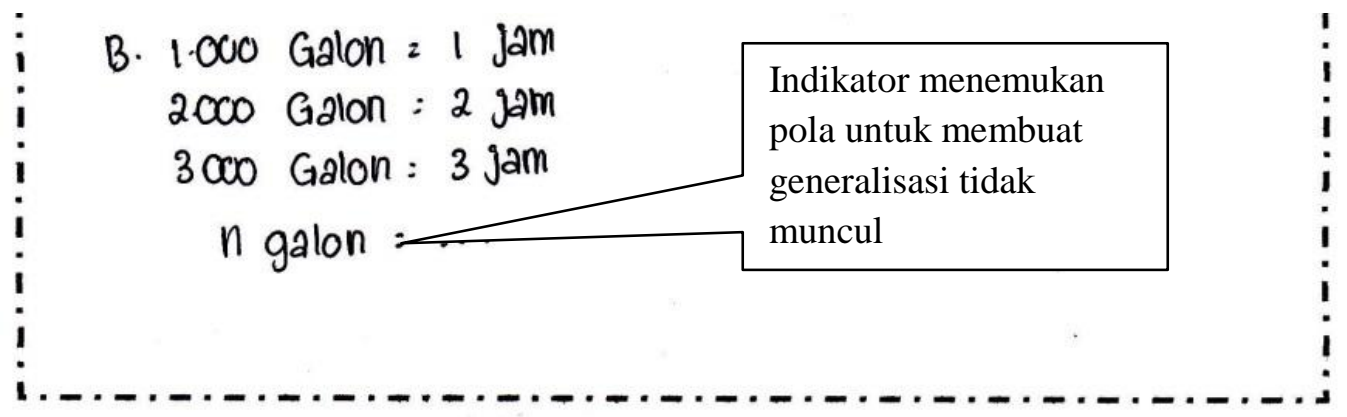

Gambar 1. Jawaban Siswa dengan Kategori Baik

$\mathrm{P}$ : Kenapa soal ini tidak selesai jawabannya?

S2 : Iya bu. Saya kebingungan menyelesaikannya. Tidak paham bu

$\mathrm{P}$ : Kalau pakai cara perbandingan bisa nggak?

$\mathrm{S} 2$ : Saya bingung bu. Jadi tidak terpikirkan menggunakan cara perbandingan.

$\mathrm{P}$ : Jadi, memang tidak paham dalam menyelesaikannya?

$\mathrm{S} 2$ : Iya bu.

$\mathrm{P}$ : Dari yang diketahui di soalnya, apa yang Shelly tidak paham?

S2 : ...(Diam). Yang $\boldsymbol{n}$ ini bu yang membuat bingung

$\mathrm{P}$ : Jadi yang $\boldsymbol{n}$ ini yang membuat bingungnya?

S2 : Iya bu, itulah tidak paham.

Selain itu, terdapat 2 atau 6,25\% siswa yang nilainya merupakan kategori kurang. Peneliti melakukan analisis data siswa yang dikategorikan kurang. Dari tujuh indikator kemampuan penalaran, hanya empat indikator kemampuan penalaran yang muncul. Adapun indikator kemampuan penalaran yang muncul dari hasil tes yaitu menyajikan pernyataan matematika secara tertulis, memperkirakan jawaban dengan menggunakan data yang mendukung, melakukan manipulasi matematika, dan menarik kesimpulan.

Pada indikator memberikan alasan dengan menggunakan model, fakta, sifat-sifat, dan hubungan serta memeriksa perkiraan jawaban yang telah ditentukan tidak muncul dikarenakan penyelesaian yang dikerjakan oleh siswa dengan kemampuan penalaran kurang masih kurang tepat. Pada Gambar 2 terlihat bahwa siswa masih kurang tepat dalam memahami pernyatan-pernyataan pada soal. Sehingga menyebabkan kesalahan penyelesaian yang kerjakan. 


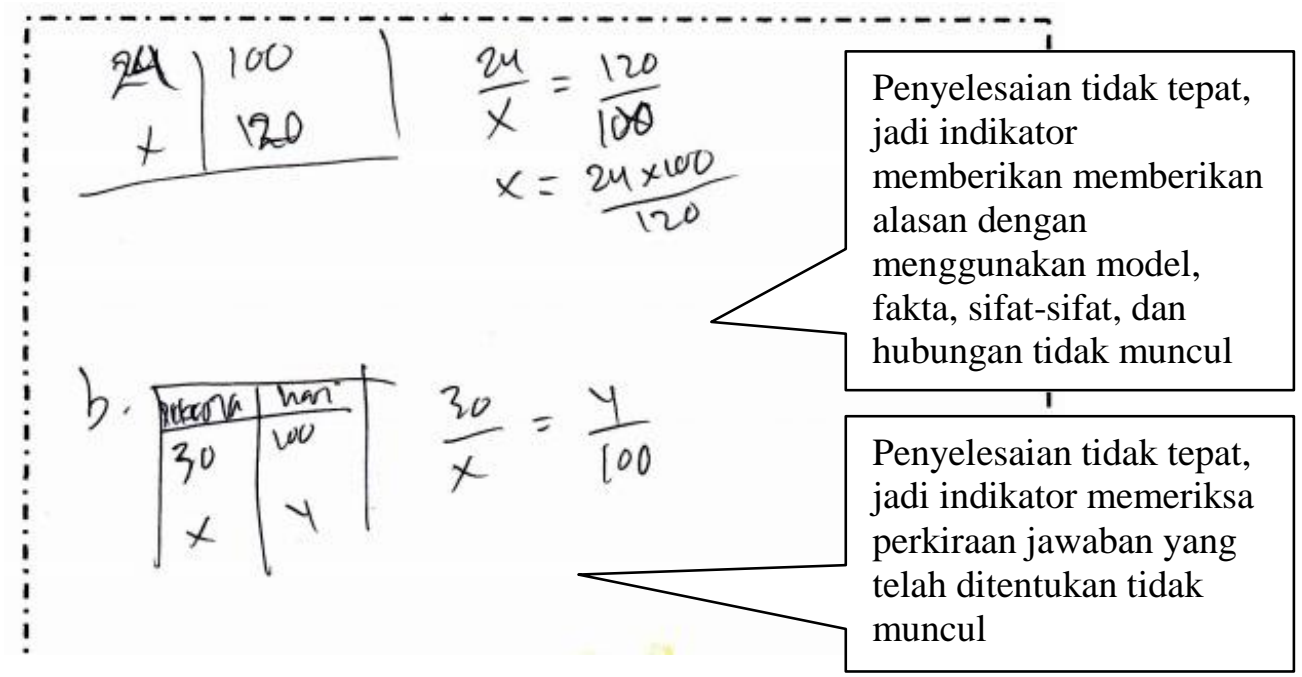

Gambar 2. Jawaban Siswa dengan Kemampuan Penalaran Kurang

$P$ : Dari mana didapatkan120 dari tabel ini?

S4 : Oh iya bu, ini saya tambahkan 20 hari yang berhenti bekerja bu.

$P$ : Jadi $100+20$ ?

S4 : Iya bu, jadi 120.

$P$ : Nah coba jelaskan dari mana diperoleh $\boldsymbol{x y}$ ini?

S4 : Ini saya tulis aja bu, karena sebenarnya saya kurang paham dengan soalnya.

Dari percakapan tersebut tampak bahwa siswa masih belum memahami soal dengan baik. Dengan interpretasi yang kurang tepat, menyebabkan penyelesaian yang dikerjakan juga kurang tepat. Sehingga indikator memberikan alasan dengan menggunakan model, fakta, sifat-sifat, dan hubungan serta memeriksa perkiraan jawaban yang telah ditentukan tidak muncul.

Dari semua kategori kemampuan penalaran matematis siswa, bahwa indikator menarik kesimpulan dari pernyataan masih belum terpenuhi dengan baik. Berdasarkan hasil tes juga bahwa ketercapaian indikator menarik kesimpulan dari pernyataan hanya sebesar 38,02\%. Mengenai indikator menarik kesimpulan memang masih banyak siswa yang kebingungan dalam membuat kesimpulan. Hal ini juga terlihat pada saat pembelajaran pertemuan I dan II, hanya beberapa siswa saja yang dapat membuat kesimpulan dengan tepat serta digiring peneliti. Berdasarkan pernyataan dari guru, memang dalam pembelajaran siswa jarang dilatihkan dalam membuat kesimpulan.

\section{SIMPULAN}

Berdasarkan hasil penelitian di kelas VIIIA SMP Negeri 1 Indralaya Utara, maka diperoleh gambaran kemampuan penalaran matematis siswa dengan menggunakan pendekatan Metaphorical Thinking pada materi perbandingan dapat dikategorikan cukup 
dengan rata-rata skor akhir 58,84. Adapun rincian persentasenya sebagai berikut: persentase siswa yang memiliki kemampuan penalaran matematis dengan sangat baik sebesar 6,25\%, persentase siswa dengan kemampuan penalaran matematis baik adalah sebesar 28,12\%, persentase siswa dengan kemampuan penalaran matematis cukup adalah sebesar 59,38\%, persentase siswa dengan kemampuan penalaran matematis kurang adalah sebesar 6,25\%, dan persentase siswa dengan kemampuan penalaran sangat kurang adalah $0 \%$. Persentase kemunculan indikator kemampuan penalaran yang paling tinggi yaitu menyajikan pernyataan matematika secara tertulis sebesar 92,97\%, sementara persentase kemunculan indikator kemampuan penalaran yang paling rendah yaitu indikator menemukan pola atau sifat dari gejala matematis untuk membuat generalisasi yaitu sebesar $28,91 \%$.

\section{DAFTAR PUSTAKA}

Afrilianto, M. (2012). Pembelajaran Matematika dengan Pendekatan Metaphorical Thinking untuk Meningkatkan Pemahaman Konsep dan Kompetensi Strategis Matematis Siswa. Tesis, Bandung: Pendidikan Matematika Universitas Pendidikan Indonesia.

Arikunto, S. (2011). Dasar-dasar Evaluasi Pendidikan. Jakarta: Rineka Cipta.

Hendriana, H. (2012). Pembelajaran Matematika Humanis dengan Metaphorical Thinking untuk Meningkatkan Kepercayaan Diri Siswa. Infinity, (hal. 90-103).

Mullis, I., dkk. (2012). TIMSS 2011 International Result in Mathematics. United States: TIMSS \& PIRLS International Study Centre.

Muthmainnah. (2014). Meningkatkan Kemampuan Representasi Matematis Siswa Melalui Pendekatan Pembelajaran Metaphorical Thinking. Skripsi, Jakarta: Pendidikan Matematika UIN Syarif Hidayatullah.

NCTM (2000). Principles and Standars for School Mathematics. Reston: The National Council of Teachers of Mathematics, Inc.

Raharjanti, M., Nusantara, T., dan Mulyati, S. (2016). Kesalahan Siswa dalam Menyelesaikan Permasalahan Perbandingan Senilai dan Berbalik Nilai. Prosiding Konferensi Nasional Penelitian Matematika dan Pembelajarannya (hal. 312-319).

Rahman, R., dan Maarif, S. (2014). Pengaruh Penggunaan Metode Discovery Terhadap Kemampuan Penalaran Analogi Matematis Siswa SMK Al-Ihsan Pamarican Kabupaten Ciamis Jawa Barat. Infinity, Vol 3, No. 1 (hal. 33-58).

Setiadi, dkk. (2012). Kemampuan Matematika Siswa SMP Indonesia Menurut Benchmark Internasional TIMSS 2011. Jakarta: Kemdikbud.

Sugiyono. (2015). Metode Penelitian Pendidikan: Pendekatan Kuantitatif, Kualitatif, dan $R \& D$. Bandung: Alfabeta.

Thompson, J. (2006). Assesing Mathematical Reasoning: An Action Research Project. www.tp.edu.sg/files/..assesing.reasoning.pdf. Diakses pada 09 April 2016.

Widjaja, W. (2010). Design Realistic Mathematics Education Lesson. Disajikan dalam Seminar Nasional Unsri, 1 Mei 2010, FKIP Unsri Palembang. 